\section{Eirik Kydland}

Redaktør i musikktidsskriftet ENO

Foto Rune Mortensen

\title{
Med øret mot kroppen
}

\section{Musikken stimulerer vårt intellekt og følelsesliv, men har du prøvd å lytte med musklene?}

For en legmann er det lett å ta kroppen for gitt. Hjertet pumper. Brødskivene man putter i munnen, omformes til energi. Leddene smøres stadig av væske som skilles ut i leddhinnene. Uten at vi merker det, arbeider nyrer, lever og alle mulige kjertler kontinuerlig der inne. Og uten å måtte anstrenge oss noe særlig puster vi med avanserte lunger. Sjelden tenker vi over alle disse minimiraklene som hvert minutt finner sted inni oss. Kroppens finstemte mekanikk gjør bare den jobben den skal.

Nylig oppsøkte jeg en lege i forbindelse med en innebandyskade i kneet. Mitt forhold til skaden var pragmatisk: Noe teknisk var galt. Jeg ønsket å få det reparert. Det var som om jeg skulle ta med en ødelagt bil til verkstedet. Selv om skaden påvirket meg i dagliglivet, så jeg egentlig ikke på den som en del av meg. Det var inntil legen hentet frem en flere centimeter lang nål for å sprøyte kortison inn i kneet.

Idet han stakk nålen inn, rett til side for kneskålen, i det myke, men knudrete og bruskaktige området der, svimlet det for meg. Jeg så nålen forsvinne lenger og lenger inn og begynte straks å visualisere materien den beveget seg gjennom på andre siden av huden. Ikke vet jeg hvordan et kne ser ut på innsiden, men jeg forestilte meg en gåtefull sfære, som en liten galakse fylt med tåkete væske, gelélegemer og abstrakte konstruksjoner av brusk. Plutselig var det som om jeg kunne kjenne blodet sirkulere. Det boblet, dirret og sildret i leddet. I et øyeblikks klarhet sanset jeg hvordan kroppen syslet med sitt livsviktige arbeid. Hrpmf, gryntet jeg og sank blek sammen på legebenken.

Hva skjedde? Antakelig sank blodsukkeret fordi jeg er en pingle når det kommer til sprøyter. Hjernen ropte: Legg deg ned, du kommer til å besvime! At jeg konsentrerte meg sånn om punktet der nålen ble stukket inn, fikk meg i tillegg til å rette oppmerksomheten mot kroppen på en annen måte enn til vanlig. Samtidig var det noe kjent med følelsen, noe som minnet om helt andre ting enn medisinsk utstyr og lukt av linoleum.

Man hører gjerne at folk blir «blåst i bakken» av musikk, da gjerne brukt billedlig om en ekstra heftig og emosjonell musikkopplevelse. Samtidig kan musikk ha en rent fysisk påvirkning på oss. Som Friedrich Nietzsche skal ha sagt: «Vi lytter til musikk med våre muskler». Følelsen jeg gjenkjente der jeg lå dånende på legekontoret, var å bli berørt av musikk. Som med kortisonsprøyta i kneet har nemlig musikk fått meg til å rette oppmerksomheten mot øyeblikket og mot kroppen på en spesiell måte.

Særlig har det skjedd med sjangre som metal, støy og klubbmusikk. Dette er musikkformer som Nietzsche sikkert ville beskrevet som «dionysiske», og forbindes gjerne med voldsom energi, høyt volum og eksplosivitet. Og bass. Dyp bass. Å stå foran scenen når black metal-bandet Mayhem spiller, er for eksempel rene massasjen. Lydbølgene lyner mot deg som et tusentalls akupunkturnåler.

På min første konsert med støyduoen Jazzkammer følte jeg en reell kvalme. Innvollene ble rystet på samme måte som når man kjører berg- og dalbane. Musikerne sendte dessuten ut høy- og lavfrekvente lyder som ørene og hjernen liksom strevde etter å få med seg. Det knirket i hodet.

Er du en rutinert klubbgjenger med spesiell interesse for bass, vet du at det er mulig å spore opp lokalets beste bassplass. Det oppleves som en slags sentrifuge eller et vakuumrom, der det smeller voldsomt i kroppens nedre halvdel. Den amerikanske journalisten Dave Tompkins har skrevet om den bassfikserte hiphop-varianten miami bass at den er «solely dedicated to fusing a subwoofer waveform with the human rear end, as if trying to develop a new biotechnology called Bottom, making these exaggerations of low end indistinguishable from each other».

Med så taktile musikkopplevelser er grensen mellom behag og ubehag ofte tynn. Ta for eksempel myten om «den brune tone». Det sies at det skal være mulig å mane frem en lavfrekvent lyd øret ikke kan sanse, men som umiddelbart lammer tilhørernes tarmfunksjoner slik at de gjør i buksene. Personer skal også ha fått påvirket hjerterytmen eller opplevd at lungene har kollapset på grunn av kraftig bass. Lyd er mektige saker. Det amerikanske forsvaret har i en årrekke eksperimentert med å utvikle soniske våpen som kan få fiender til å besvime eller brekke seg.

Musikk omtales gjerne som åndelig $f ø$ de. Men minst like verdifull er den musikken som berører oss rent fysisk. Nettopp fordi den dulter borti oss og får oss til å huske hvilket sårbart og fascinerende maskineri kroppen er.

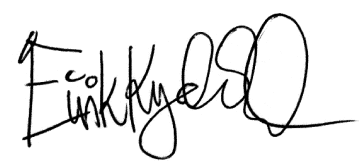

